\title{
Ensuring a Quality Physical Education Teacher 優質體育教姉的素質
}

\author{
Kaila CAPOUCH \\ Physical Education Teacher \\ West Fargo Public Schools, U.S.A. \\ Joe DEUTSCH \\ Professor of Physical Education and Coaching \\ North Dakota State University, U.S.A.
}

\begin{abstract}
Children are living more sedentary lifestyles today than ever before in America. Physical education teachers need to be our leaders for change by promoting the importance of maintaining a healthy body and mind in today's youth and promoting life-long physically activity. This article helps to shape the mind of a physical educator and gives them a "don't" list to make sure are not happening in their classes, if they want students to have a positive PE experience and potentially go on to be life-long physically active learners. From not letting the students pick their own teams to not playing games that eliminate them from competition, the role that the PE teacher plays in shaping students life-long beliefs about the joy of exercise is substantial.
\end{abstract}

\section{Introduction}

Living a healthy lifestyle involves eating right, exercising regularly and making healthy decisions regarding our body and mind. Studies have shown that today's youth are living a sedentary life style by watching television, playing video games or using technical devices. The rise of obesity is a growing epidemic amongst adolescence in the U.S. We need to put an end to childhood obesity by advocating a healthy lifestyle. Physical education (PE) teachers need to be our leaders by promoting the importance of maintaining a healthy body and mind in today's youth by promoting life-long physically activity. Le Masurier and Corbin (2006) said it best when they said, "Quality physical education represents our best opportunity to provide all children with physical activity experiences that promote physical activity now and for a lifetime" (p.44).
Life is full of experiences which shapes our attitude and behaviors on certain aspects of our lives. As we go through life we have bad experiences in which we dread to experience again. If students have a negative experience with physical activity at an early age, they may incorporate a negative perspective towards physical activity forever. In Stream's 2009 study, a participant commented, "Physical education robbed me of the joy of physical activity for many years..... It destroyed my physical confidence" (p. 217). They can even become anxious when they have to participate in an activity or game in PE class. PE teachers need to shape positive experiences for all students so they feel confident and comfortable participating in physical activity. PE teachers also need to create a positive learning environment for all students and can do so by using appropriate instructional practices and possessing certain teaching qualities that can shape today's youth. We need students to experience joyful memories of physical education so they can stay active for a lifetime. 
PE teachers need to have appropriate instructional lessons. The inappropriate practices that PE teachers use in their classroom setting puts students in harmful situations physically or emotionally and can shape a negative attitude towards physical activity. Here are a list of inappropriate instructional practices PE teachers shouldn't do in their classroom settings.

\section{Don't Let Students Pick their Own Teams.}

This approach is known as the "pecking-order." Students who are chosen first are either the popular student or physically gifted. Students who are chosen last by their peers are displayed as not being good enough. This inappropriate instructional practice can cause a negative experience for students. A study done by Strand and Bender (2011) described the negative experience as being emotionally harmful, embarrassing, ashamed, and resulting in diminished self-confidence. The study also showed students who endured this experience were significantly less active than their peers. Teachers should always organize students into equally talented teams so these negative experiences can be avoided.

\section{Don't Let Students Play Inappropriately Constructed Games or Activities.}

Games or activities that are a high risk for injury are considered inappropriate. Even though students love playing dodge ball, it is a high risk game for injury. The sole purpose of this game is to purposely throw objects at the other opponent. Anytime a game or activity involves a student being a primary target, there is a foreseeable risk and if injury occurs a teacher could be considered negligent. This popular game doesn't have to be thrown out of lesson plans. PE teachers could modify dodge ball so students aren't targets and less likely to risk injury (Deutsch, 2007).

\section{Don't Put Students on Display.}

Students that are physically gifted at athletics enjoy the spot light during PE class. Student that struggle with athletics don't feel comfortable to perform activities or skills in front of their peers. Having a student demonstrate to the class is acceptable when a student volunteers. It is completely different when you pick a student to perform in front of class that doesn't feel comfortable about their ability. This could cause anxiety for the student and embarrass them if they perform the skill inadequately. This experience could shape a negative attitude or behavior towards physical activity. Not only could it hinder their participation in the physical education setting, but also their long-term physical activity later in life.

\section{Don't Use Exercise as Punishment.}

Students sit all day in classes. It's important to incorporate activity that allows them to move and burn energy. When students attend PE class, most are elated and extremely appreciative of the opportunity. The gym is the proper place to get the body moving by burning off energy and relieving stress. This pent up energy also causes behavioral issues among some students. When behavioral issues arise it's important for PE teachers not to use exercise as a punishment. For an example, if a student is being disruptive while a teacher is going over skills with the class, it wouldn't be an appropriate teaching practice for the PE teacher to yell at the student and tell them to run five laps while they go back to instructing students. When exercise is used to discipline behavior problems, students can perceive exercise as a negative experience. If negative consequences are associated with physical activity, students will be less likely to participate in physical activity on their own time.

\section{Don't Play Games That Eliminate Students From Participation.}

Students are supposed to be physical activity for 60 minutes a day. Depending on the state and school system most students only have PE class every other day. Since student's activity levels are reduced during the day due to school, it's vital for students to be active when they have PE. PE teachers need to design activities and skills that keep students vigorously active during class. Games that eliminate students are an inappropriate practice because it takes away from their recommended physical activity. An original tag game is a prime example of elimination game. During tag, if a student gets tagged, they are eliminated from the game or become frozen in the game. If they are eliminated or frozen during the game they are nonactive by standing still and watching everyone else 
play the game. These games still can be played if they are modified to allow students to be physically active throughout the game, hence a non-elimination tag game.

\section{Don't Play Games That Have Low Participation Time Factors.}

As previously stated, we have limited time with our students to teach them skills they can use for a lifetime to stay active. Once the skills are learned, students need to be active to get into a proper target heart rate zone. Activities or games that have a low activity level should either be modified to be more activity or not played during class time. A great example of a low participation game is kickball. If 25 students are participating in a kick ball game, how many students are being active at a time? The only student being active is the person kicking the ball and the defender chasing the ball. The rest are standing still and observing the two active players. Again, this game can be modify for students to be more active during play. Some modifications could include:

a) Having more than one kicker at a time.

b) Using large mats as bases and allowing multiple players on them at a time.

c) Getting the offensive player out by having the defense run to a certain area, with control of the ball, before offensive player gets on base.

Its important to analyze games or activities to make sure the majority of students are moderate to vigorously active during play. If they arent, make simple modifications, to allow them to be more active.

\section{Don't "Roll out the Ball".}

The expression "roll out the ball" means playing a game without teaching any skills. Students need to be taught the proper skills so they can be successful when participating in games or activities. We are all creatures of habit, most of the time we avoid certain things we don't excel at. If we teach students at a young age the proper skills, they feel confident using these in front of their peers and on their own. Our goal as PE teachers is to teach them skills they can use for a life time, so they are physically active!
Students are recommended to be active for 60 minutes a day to maintain a healthy body and mind. PE teachers need to be our leaders by promoting the importance of being active daily. They need to be mindful of all student's skill levels and create an environment in which all students have a positive experience and can succeed. Lavin (2008) emphasized the "PE plays a key role in improving the long-term health and well-being of our children" (p.27). A well-rounded physical education teacher develops a program that emphasizes skill development, creates a safe and active learning environment, and promotes physical activity for a lifetime!

\section{References}

Cardinal, B., \& Cardinal, M. (2013). Negative experiences in physical education and sport: How much do they affect physical activity participation later in life? Journal of Physical Education, Recreation \& Dance, 84(3), 49-53.

Deutsch, J. (2007). From hall of shame to hall of fame: Transforming traditional elementary activities. Missouri Journal of Health, Physical Education, Recreation and Dance, 17, 48-52.

Le Masurier, G., \& Corbin, C. (2006). Top 10 reasons for quality physical education. Journal of Physical Education, Recreation \& Dance, 77(6), 44-53.

Stream, W. (2009). Remembering instructors: Play, pain and pedagogy. Qualitative Research in Sport and Exercise, 1, 210-220.

Williams, N. (2015). The Physical Education Hall of Shame, Part IV: More Inappropriate Games, Activities, and Practices. Journal of Physical Education, Recreation \& Dance, 86 (number 1), 3639.

\section{Correspondence}

Dr. Joe Deutsch

North Dakota State University

Email: Joe.Deutsch@ndsu.edu 